\title{
RUOKINNAN VAIKUTUS SINIKETUN JALKOJEN TAIPUNEISUUTEEN
}

\author{
Hannu T. Korhonen ${ }^{1}$, Pekka Eskeli ${ }^{1}$ ja Juhani Sepponen ${ }^{2}$ \\ ${ }^{1}$ Luonnonvarakeskus, Luke, Silmäjärventie 2, 69100 Kannus; hannu.t.korhonen@luke.fi \\ ${ }^{2}$ Luonnonvarakeskus, Luke, Halolantie 31 A, 71750 Maaninka
}

\section{TIIVISTELMÄ}

Sinikettujen koko on kasvanut viime vuosina huomattavasti. Koon kasvaessa myös jalkojen heikkous ja jalkaongelmat ovat lisääntyneet. Tämän kokeen tarkoituksena oli selvittää ruokinnan voimakkuuden (rajoitettu vs vapaa) ja Ca:P.suhteen (1.5.1 vs 2:1 vs2.9.1) vaikutusta siniketun jalkaterveyteen. Kokeen aikana mitattiin eläinten kasvuun ja hyvinvointiin liittyvät muuttujat sekä rehunkulutus. Eläinten liikuntavaikeudet ja taipuneisuus arvioitiin. Etujaloista otettiin röntgenkuvat. Kokeessa onnistuttiin tuottamaan painon suhteen kaksi hyvin erilaista ryhmää; (1) lihavat, vapaasti ruokitut, ja (2) selvästi hoikemmat, rajoitetusti ruokitut. Vapaasti ruokittujen kettujen kasvukäyrät olivat selvästi rajoitetuista poikkeavat. Samoin merkittävät erot löytyivät vyötärön ja niskan ympärysmitoissa, pituudessa ja kuntoindeksissä. Ruokinnan voimakkuus vaikutti liikkumisvaikeuteen: vapaasti ruokituilla oli enemmän liikkumisvaikeuksia. Mitä painavampi kettu oli, sitä suuremmat olivat liikuntavaikeudet. Liikkumisvaikeuksia oli enemmän niillä ketuilla, joilla oli enemmän taipuneisuutta jaloissa. Ruokinnan voimakkuus ei vaikuttanut jalkojen taipuneisuuteen. Jalkojen taipuneisuus oli suurinta alhaisen Ca:Psuhteen dieetillä (1.5.1) ja vähäisin korkealla Ca:P dieetillä (2.9:1). Röntgenkuvat eivät paljastaneet jaloissa mitään hälyttävää. Luustossa (värttinäluu, kyynärluu) ei näkynyt poikkeavaa eikä myöskään nivelissä (rannenivel, kyynärnivel). Jalkojen Taipuneisuus arvioitiin asteikolla 1-5, missä 1 oli täysin terve ja 5 oli erittäin taipunut. Tässä kokeessa löytyi kettuja, joiden taipuneisuus oli 2,3 tai 4 . Siis ääripäitä ei löytynyt. Ketun pituuskasvu loppuu syyskuun lopulla. Lihomisvaihe ajoittuu loka-marraskuulle. Näyttää siltä, että jalkojen taipuminen näin lyhyellä ajanjaksolla ei ole kovinkaan suuri hyvinvointiongelma nahkottavalle ketulle.

Asiasanat: Sinikettu, hyvinvointi, jalkaterveys, lihavuus, liikuntavaikeudet 


\section{Johdanto}

Viime vuosikymmeninä sinikettujen koko on kasvanut huomattavasti. Nykyisin nahkonta-aikana sinikettujen paino vaihtelee yleisesti $15-20 \mathrm{~kg}$, kun vastaavasti noin 30 vuotta sitten nahkontapaino oli alle $10 \mathrm{~kg}$. Nahkontapainon kasvu aiheutuu osittain rajoittamattoman eli ad libitum-ruokinnan ja rehun korkean rasvapitoisuuden vuoksi. Kuitenkin myös ketun koko on kasvanut ja samanaikaisesti jalkojen heikkous ja jalkaongelmat, kuten etujalkojen vääntyminen ovat lisääntyneet. Jalkaheikkouden taustoja ja problematiikkaa ei ole tutkittu yksityiskohtaisesti ja voidaan olettaa, että jossain määrin se on monen tekijän yhteisesti aiheuttama ongelma. Oletettavissa on, että sub-optimaalinen ravinto on yksi jalkaongelmia aiheuttavista tekijöistä. Yksi tärkeimmistä ravitsemuksellisista tekijöistä on ravinnon kalsiumin (Ca) ja fosforin (P) määrä sekä niiden keskinäinen suhde rehussa.

Viimeaikaisimmissa tutkimuksissa rehun kalsiumin ja energiansaannin vaikutusta osteokondroosin ja jalkaheikkouden kehittymiseen selvitettiin kahdessa tutkimuksessa kasvavilla siniketuilla heinäkuun puolivälistä lokakuun alkuun (Korhonen ym. 2005). Tutkittavina käsittelyinä olivat normaali ja alhainen rehun energiataso sekä normaali ja alhainen Ca-taso rehussa. Kuitenkin tutkimuksessa alhainen Ca-taso oli lähes 3 kertaa suurempi (16 g / kg KA) kuin NRC:n (1982) suositusten mukainen ja normaali Ca-taso ei poikennut merkittävästi alhaisen Ca-tason rehusta. Tutkimus ei pystynyt tuottamaan mitään selkeää kalsiumin saannin vaikutusta kettujen jalkaterveyteen, vaikkakin luuston $\mathrm{Ca}$ ja $\mathrm{P}$-pitoisuus oli korkeampi normaalin kuin matalan kalsiumin ryhmissä. Muut ominaisuudet esim. luiden murtolujuus, olivat riippumattomia Ca-tasosta, rehun energian saannilla oli taipumusta vaikuttaa enemmän mitattuihin vasteisiin kuin rehun kivennäistasoilla (Korhonen ym. 2005).

Jos ketun suuren koon valinta on johtanut fysiologiseen adaptaatioon, kuten on havaittu muilla eläinlajeilla, voi olla mahdollista että ruokinnan $\mathrm{Ca}$ ja $\mathrm{P}$ saanti ja ruokintastrategiat pitäisi muuttaa, jotta voidaan tukea luuston ja nivelten kehittymistä (Korhonen ym. 2014; 2015). Siksi kettujen nopean varhaiskasvun aikaisen $\mathrm{Ca}$ ja P tarpeen tutkiminen on välttämätöntä. Tämän tutkimuksen tavoitteena oli selvittää Ca:n saannin sekä Ca:n ja P:n tasapainon sekä ruokintaintensiteetin (vapaa vs rajoitettu) vaikutusta sinikettujen (Vulpes lagopus) jalkaterveyteen.

\section{Aineisto ja menetelmät}

Koeryhmät olivat seuraavat: (1) Kontrolli: ketunrehu, tämänhetkinen Ca ja P pitoisuus (2.0:1), vapaa ruokinta. (2) Alhainen Ca, Ca:P suhde 1.5:1., vapaa ruokinta.(3) Korkea Ca ja normaali P, "vinoutunut" Ca:P, $\mathrm{Ca}: \mathrm{P}$ suhde 2.9:1, vapaa ruokinta. (4) Kontrolli: ketunrehu, tämänhetkinen Ca ja P pitoisuus (2.0:1), rajoitettu ruokinta 60\%. (5) Alhainen $\mathrm{Ca}, \mathrm{Ca}: \mathrm{P}$ suhde 1.5:1., rajoitettu ruokinta 60\%. (6) Korkea Ca ja normaali P, "vinoutunut" Ca:P suhde: Ca:P suhde 2.9:1, rajoitettu ruokinta $60 \%$.

Kokeen aikana mitattiin eläinten kasvuun ja hyvinvointiin liittyvät muuttujat sekä rehunkulutus. Eläinten liikuntavaikeudet ja taipuneisuus arvioitiin. Etujaloista otettiin röntgenkuvat (Korhonen ym. 2015).

\section{Tulokset ja tulosten tarkastelu}

Kokeessa onnistuttiin tuottamaan painon suhteen kaksi hyvin erilaista ryhmää; (1) lihavat, vapaasti ruokitut, ja (2) selvästi hoikemmat, rajoitetusti ruokitut. Vapaasti ruokittujen kettujen kasvukäyrät olivat selvästi rajoitetuista poikkeavat. Samoin merkittävät erot löytyivät vyötärön ja niskan ympärysmitoissa, pituudessa ja kuntoindeksissä. Ruokinnan voimakkuus vaikutti liikkumisvaikeuteen: vapaasti ruokituilla oli enemmän liikkumisvaikeuksia. Mitä painavampi kettu oli, sitä suuremmat olivat liikuntavaikeudet. Liikkumisvaikeuksia oli enemmän niillä ketuilla, joilla oli enemmän taipuneisuutta jaloissa. Ruokinnan voi- 
makkuus ei vaikuttanut jalkojen taipuneisuuteen. Jalkojen taipuneisuus oli suurinta alhaisen Ca:P-suhteen dieetillä (1.5.1) ja vähäisin korkealla Ca:P dieetillä (2.9:1). Röntgenkuvat eivät paljastaneet jaloissa mitään hälyttävää. Luustossa (värttinäluu, kyynärluu) ei näkynyt poikkeavaa eikä myöskään nivelissä (rannenivel, kyynärnivel). Jalkojen Taipuneisuus arvioitiin asteikolla 1-5, missä 1 oli täysin terve ja 5 oli erittäin taipunut. Tässä kokeessa löytyi kettuja, joiden taipuneisuus oli 2,3 tai 4. Siis ääripäitä ei löytynyt.

Tässä kokeessa eläinten perinnöllinen tausta otettiin erityisesti huomioon eli kuhunkin koeryhmään tuli eläin samasta pentueesta. Tämä mahdollisti ruokinnan voimakkuuden ja Ca:P suhteen vaikutusten paremman selvittämisen. Kuten kokeen kasvutiedot selvästi osoittavat, onnistuimme tuottamaan eläinten painon suhteen kaksi hyvin erilaista painoryhmää: (1) lihavat, vapaasti ruokitut eläimet; ja (2) selvästi hoikemmat, rajoitetusti ruokitut eläimet. Vapaasti ruokittujen kasvukäyrät olivat selvästi rajoitetuista poikkeavat. Samoin merkittävät erot löytyivät vyötärön ja niskan ympärysmitassa, pituudessa ja kuntoisuusindeksissä. Tällä perusteella meillä oli periaatteessa hyvät mahdollisuudet vertailla ruumiinpainon ja koon vaikutusta jalkaterveyteen.

Liikkumisvaikeuden arviointi tässä kokeessa perustui samaan arviointimenetelmään kuin WelFur- protokollassa käytetään ketuille. Liikkumisvaikeuksia esiintyi kokeessa varsin vähän. Itse asiassa ei löytynyt yhtään kettua joka ei liikkuisi ollenkaan tai sillä olisi merkittäviä liikkumisvaikeuksia. Ainoastaan lievää liikuntavaikeutta löytyi. Näiltä osin ero vapaalla ja rajoitetulla ruokinnalla oli merkitsevä eli vapaalla ruokinnalla oli selvästi enemmän kettuja joilla oli lievää liikuntavaikeutta. Tämä viittaa siihen, että liiallinen ruokinta aiheuttaa jossain määrin liikkumisvaikeutta. Toisaalta jalkojen taipuneisuudella ja liikuntavaikeudella ei näytä olevan välttämättä mitään tekemistä keskenään. Jalkojen taipuneisuudessa ei ollut eroa vapaalla ja rajoitetulla ruokinnalla. Ca:P tasolla näytti toisaalta olevan lievää vaikutusta jalkojen taipuneisuuteen. Tämä vaikutus ei ollut kuitenkaan kovin selvä. Näyttää siltä että korkea vinoutunut Ca:P suhde ei ainakaan edistä taipuneisuutta. Eniten voimakasta taipuneisuutta oli vertailurehulla. Näyttääkin alustavasti siltä, että tarhoilla käytettävää perusrehua tulee edelleen kehittää. Iso kysymys tässä on se, että millä tavalla? Tämä tutkimus ei antanut siihen riittävästi selvyyttä. Tämä nykyinen koe oli osa aiemmin suunnittelemaa suurempaa jalkaterveyteen liittyvää koetta. Valitettavasti laajempaa koetta ei ole toteutettu. Tämän pienen osakokeen osalta johtopäätökset eivät ole lopullisia eikä kovin selvää eroa taipuneisuuteen saatu. Näkemyksemme mukaan tulisi tehdä vielä lisää laajempia kokeita jalkaongelmien lopulliseksi selvittämiseksi. Jalkaongelmat näyttävät olevan monen tekijän summa.

\section{Johtopäätökset}

Ruokinnan voimakkuus vaikutti liikkumisvaikeuteen: vapaasti ruokituilla oli enemmän liikkumisvaikeuksia. Mitä painavampi kettu oli, sitä suuremmat olivat liikuntavaikeudet. Liikkumisvaikeuksia oli enemmän niillä ketuilla, joilla oli enemmän taipuneisuutta jaloissa. Ruokinnan voimakkuus ei vaikuttanut jalkojen taipuneisuuteen.

\section{Kirjallisuus}

Korhonen, H.T., Happo, M., Rekilä, T., Valaja, J. \& Pölönen, I. 2005. Effects of diet calcium: phosphorous ratio and metabolizable energy content on development of osteochondrosis, foot bending and performance in blue foxes. Animal Science 80: 325-331.

Korhonen, H.T., Eskeli, P., Lappi, T., Huuki, H. \& Sepponen, J. 2014. Effects of feeding intensity and $\mathrm{Ca}: \mathrm{P}$ ratio on foot welfarre in blue foxes (Vulpes lagopus). Open Journal of Animal Sciences 4: 153-164.

Korhonen, H.T., Eskeli, P., Huuki, H. \& Sepponen, J. 2015. Foreleg bending in blue foxes (Vulpes lagopus) as evaluated by radiography. Open Journal of Veterinary Medicine 5: 61-67.

NRC, 1982. Nutrient requirements of mink and foxes. National Research Council, National Academy Press, Washington D.C. 